\title{
Application of biofungicides in control of damping disease off in greenhouse crops as a possible substitute to synthetic fungicides
}

\author{
${ }^{1 *}$ H. R. Zamanizadeh; ${ }^{2}$ N. Hatami; ${ }^{3}$ M. M. Aminaee; ${ }^{1}$ F. Rakhshandehroo \\ ${ }^{1}$ Department of Plant Pathology, School of Agriculture and Natural Resources, Science and Research Branch, Islamic \\ Azad University, Tehran, Iran \\ ${ }^{2}$ Department of Plant pathology, School of Agriculture, Payam Nour University, Kerman, Iran \\ ${ }^{3}$ Department of Plant Pests and Diseases Research, Kerman Agriculture Research Center, Kerman, Iran \\ Received 7 August 2010; $\quad$ revised 12 October 2010; accepted 18 November 2010; available online 1 December 2010
}

\begin{abstract}
The purpose of this study was to evaluate the effectiveness of a commercial biofungicide such as Trichomix-HV in controlling damping-off disease in cucumber seedlings of greenhouses. In this regard, 504 fungal isolates were collected from greenhouses at 31 districts in city of Jiroft in Iran. Pythium aphanidermatum, P.ultimum, $P$. irregulare, Phytophthora drechsleri, and Ph. melonis accounted for 9.9 \%, 8.3 \%, $4.5 \%, 4.9 \%$, and $21 \%$ of total isolates collected, respectively. Isolates of $P$. aphanidermatum obtained from commercial cucumber in greenhouses were tested in vitro and under greenhouse conditions for sensitivity to chemical and biological treatments. To this aim, Trichomix-HV a commercial formulation of Trichoderma harzianum strain T969 and the fungicides Metalaxyl and Metalaxyl MZ were amended into the culture medium as well as into sterilized or non-sterilized greenhouse soils inoculated by the pathogen and containing plants at the seedling stage. Trichomix-HV significantly $(\mathrm{P}<0.001)$ reduced seedling infection at a rate of $82 \%$ when applied into soil medium at a concentration of $10^{7}$ conidia $\mathrm{ml} / \mathrm{L}$ and reduced vegetative growth of Pythium aphanidermatum in vitro. The result from this study shows that Trichomix-HV can be effectively used as a biocontrol agent for controlling damping-off cucumber seedlings and having the potential to replace chemical fungicides as a mean of disease control.
\end{abstract}

Keywords: Biocontrol; Greenhouse; Synthetic Fungicides; Trichoderma harzianum

\section{INTRODUCTION}

Production of cucumbers (Cucumis sativus) in Iran has expanded consistently over the last 10 years and making cucumber as one of the fastest growing agricultural products in Iran. City of Jiroft is ranked fourth in the production of cucumber in Iran, especially in soil-based greenhouse cucumbers (Mubli and Pirasteh 1995.; Yedidia, et al.; 1999). Different species of Oomycetes, belonging to Phytophthora and Pythium cause very similar damage to cucumber seed and seedlings, being virtually indistinguishable without laboratory tests. These pathogens damage seed root, pre-emergence damping-off, and postemergence damping-off, often associated with tanbrown, soft, rotted tissue (Igwe et al., 2008; Malakootian et al., 2009). They can cause serious

\footnotetext{
\*Corresponding Author Email: hzamani@srb.iau.ac.ir
} Tel.: +9821 22400247; Fax: +982161002405 damage under favorable environmental conditions (Farr et al., 1989; Weller, et al.; 2000; Siddiqui, et al., 2000). Damping-off in cucumber is a worldwide problem in greenhouses. Stanghellini and Phillips (1975) reported up to $87 \%$ mortality of cucumber seedlings in untreated greenhouse soil in Abu Dhabi. In Canada, damping-off has been reported as a serious disease of several vegetable crops including cucumber (Martin and Loper, 1999). Although other fungal pathogens such as Rhizoctonia solani and Fusarium spp. have been associated with damping-off (Lida, et al., 1983; Abbasi, et al., 2004; Vinodhini and Narayanan, 2008), Pythium spp. was shown to be the most frequent cause of damping-off in cucumber (Stanghellini and Phillips, 1975; Gubler and Davis, 1996; Deadman, et al., 2002). The continuous production of cucumbers in monoculture has been accompanied by increase in post- 
emergence damping-off disease, which has become the main limiting biotic factor to profitable production of cucumbers in greenhouses all over the world (Farr et al., 1989). One of the most common means to control plant diseases in the field, greenhouse and storage is the use of chemical compounds. Currently, several fungicides belonging to different classes of chemicals are used to protect plants from Pythium spp., including azoxystrobin (strobilurin), fosetyl-aluminum (alkyl phosphonate), mefenoxam and metalaxyl (acylanilide), etridiazole (triadiazole), and propamocarb (carbamate) (Brantner and Windels, 1998); (Goodwin and McGrath, 1995). These compounds are chemical pesticides, and the majority of them, especially fungicides and nematocides are substances potentially dangerous for environment and can be extremely toxic for consumers (Bandyopadhyay and Chattopadhyay, 2007; Cuthbertson et al., 2009a and b; Cuthbertson and Brown, 2009; Igbinosa and Okoh, 2009; Cuthbertson and Murchie, 2010). Some of them could also have adverse genetic effects, cause morphological and physiological abnormalities in test animals (Cook, 1993). For this reason, a number of restrictions are imposed in the licensing, registering and using of each chemical (Cuthbertson et al., 2010 ). In this regard, biological disease control is a promising strategy for managing soilborne or foliar diseases in a wide range of crops. Several commercial formulations of the biological control agents Trichoderma harzianum, Bacillus subtilis, Streptomyces griseoviridis, and Gliocladium virens have been reported previously for application against plant fungal pathogens in the field and greenhouse (Cook, 1993; Sutton and Peng, 1993; Lo et al., 1996; Elad and Kapat 1999; Yedidia et al., 2001; Sultana et al., 2005.). Since spread of active growing mycelium through potting mix is an important means of spread of Pythium and Phytophthora species, disease control strategies were targeted to prevent seedling infection and reduce pathogen growth in the soil. (Altomare et al., 1999) The main objective of the present study was to evaluate in vitro and in vivo the effect of the commercially available biofungicide Trichomix-HV, based on the biocontrol agent Trichoderma harzianum, against the soilborne pathogen Pythium aphanidermatun. (Obire and Anyanwu 2009). In different trials on cucumber seedlings under greenhouse condition, the efficacy of Trichomix-HV was compared with that of two synthetic fungicides (Metalaxyl and Metalaxyl MZ) commonly applied on this vegetal crop. Present research was carried during 2006 to 2008 in the province of Kerman, Iran.

\section{MATERIALS AND METHODS}

Collection and identification of Pythium isolates

A survey during 2006 and 2008 was made in different greenhouses in the 31 districts of Jiroft where more than $87 \%$ of all greenhouses are located. $P$. aphanidermatum was isolated from roots and crowns of cucumber seedlings showing damping-off symptoms including leaf yellowing, leaf wilting and rotting in the collar and crown parts. Isolates were recovered from the crown and roots of infected cucumber plants grown in commercial greenhouses. The sample size varied between times of the year and district. Isolations were carried out by washing soil debris from roots and crowns, which were surface-sterilized in $70 \%$ ethanol for 30s. Seedling tissue was then disinfected with sodium hypochloride ( $1 \%$ active chlorine) for $2 \mathrm{~min}$, washed in sterile distilled water for $1 \mathrm{~min}$ and dried on sterile filter paper (Tsao, 1983; Shafizadeh, 2003). Tissue was plated onto water agar medium in $100 \times 15 \mathrm{~mm}$ Petri dishes. Dishes were incubated under ambient laboratory conditions (20 to $23^{\circ} \mathrm{C}$ ), under fluorescent lights (12-h photoperiod) for approximately 10 days, after which time the pathogen was transferred to $1.7 \%$ corn meal agar (CMA) amended with 5ìg pimaricin (Davet and Rouxel, 2000), as well as on $2.5 \%$ potato dextrose agar (PDA), for 1-3 days. Monocultures were obtained by excising hyphal tips and Pythium cultures were maintained on CMA slants at $8^{\circ} \mathrm{C}$. To induce formation of asexual and sexual reproductive structures, one plug (5mm diameter) from a colony growing on amended or unamended CMA was placed on a fresh water agar (WA) plates. The inoculated plates were incubated in the dark at $22-25^{\circ} \mathrm{C}$. Sporangia, oogonia, antheridia and oospores were observed during 4 to 10 days of incubation. Identification of species was based on the monograph of Plaats-Niterink (1981). Reference isolates of Pythium species served as standards to confirm the identification.

Evaluating the antifungal activity of Metalaxyl and Metalaxyl-Mancozeb

Potato dextrose agar (PDA) at $45^{\circ} \mathrm{C}$ was amended with final concentration $0,0.01,0.1,1,10,50$ and 100 ppm Metalaxyl (Previcur Energy, Bayer) and MetalaylMancozeb (wettable powders, 72 \%, Previcur Energy, 
Bayer) and dispensed in 9-cm diameter plastic Petri plate. A 6-mm-diameter agar plug disk, taken by using a sterilized cork borer from the margin of a 5-day-old Pythium CMA culture, was transferred into the center of a new Petri dish (10 replicate plates per medium and per each isolate). Dishes were incubated in the dark at $21 \pm 1^{\circ} \mathrm{C}$ using a randomized block design with time as the blocking factor. Every $48 \mathrm{~h}$, during a period of 4 days, the linear growth of fungal colonies was measured.

\section{Testing of Trichoderma harzianum antagonist}

In order to determine the antagonistic potential of the commercial biofungicide Trichomix-HV (containing in its formulation the biocontrol agent T. harzianum, strain T969) two different types of assay including simultaneous and non-simultaneous in vitro dual culture tests were developed. According to Dennis and Webster (1971), the efficacy of Trichomix-HV against $P$. aphanidermatum by simultaneous dual culture technique on PDA medium was done as follows. A mycelial agar plug of the pathogen (6 mm diameter) was placed at one end of a pre-sterilized Petri plate and at the opposite end, a myceial agar plug (6 mm diameter) of the antagonistic fungus $T$. harzianum strain T969 was placed aseptically. After 2, 3, 4 and 5 days of incubation, the radial growth of pathogen isolates was measured and the average percentage of radial growth inhibition, with respect to fungal growth in controls, was calculated as follows: $L=[(C-T) / C] \times 100$, where $L$ is inhibition of radial mycelial growth; $\mathrm{C}$ is radial growth of the pathogen in the control; $\mathrm{T}$ is radial growth of the pathogen in the presence of Trichoderma isolates (Edington et al., 1971). Since T. harzianum grows faster than $P$. aphanidermatum, non-simultaneous dual cultures were also performed in which a $6 \mathrm{~mm}$ diameter of $P$. aphanidermatum agar plugs were taken from the growing margin of fresh cultures and cultured on PDA for 2 days before inoculating T. harzianum. Agar plugs of T. harzianum were placed $6 \mathrm{~cm}$ apart on the surface of PDA in a Petri dish. Plates were incubated at room temperature and the mycelial growth of the fungus was monitored. Percentage of mycelia growth inhibition of the commercial product Trichomix-HV against $P$. aphanidermatum was measured and calculated as described above for comparison with the treatment based on the pure culture of T. harzianum.

Evaluation of the biofungicide Trichomix-HV and chemical fungicides under greenhouse conditions

The efficacy of the biofungicide Trichomix-HV and two chemical fungicides (Metalaxyl and
Metalaxyl MZ) were compared under glasshouse condition by using a sterilized soil in comparison with $P$. aphanidermatum infected soils collected from different glasshouses. For the first set of experiments, the pot mixture was sterilized at 15 psi for two hrs at $121^{\circ} \mathrm{C}$ for two consecutive days. The sterilized pot mixture was filled in half size pots. The pathogen, $P$. aphanidermatum was mass multiplied on sand-maize medium and inoculated into the sterilized pot mixture at a rate of $5 \%(w / w)$. In the second set of experiments, $P$. aphanidermatuminfected soils collected randomly from glasshouses were mixed and used directly for the experiments. Pots were arranged in a randomized block design (five replicates per treatment) in a greenhouse at 25 $\pm 3{ }^{\circ} \mathrm{C}$ and a 12 -h photoperiod for 4 weeks. Stand counts for pathogen verification were done daily and the percentage reduction in seedling number was determined with respect to the number of seedlings in uninfected sterilized soil (control) after 30 days. The Trichomix-HV biocontrol material was used directly for seed treating or soil inoculating. For seed treatment, cucumber seeds (Cucumis sativus L. cv. Royal), were pre-soaked in water for overnight and surface sterilized with $70 \%$ (v/v) ethanol for $1 \mathrm{~min}$ and air dried in a flow hood. Trichomix-HV was incorporated into seeds at the amount of $10 \mathrm{~g}$ of biocontrol formulate per $\mathrm{Kg}$ of cucumber seeds or incorporated into soils at the amount of $50 \mathrm{~g}$ of biocontrol formulate per $\mathrm{m}^{2}$ of soil. Trichomix-HV treated and non-treated seeds were sown in pathogen contaminated soil at a density of 10 seeds per pot. In each experiment non-treated seeds and soils were considered as the control. All experiments were performed at least twice. For studying the control effect of fungicides, cucumber seedlings at the 2-3 leaf stage were subjected to treatments with the chemical fungicides Metalaxyl (5 \% WG) or Metalaxyl MZ (72 \% WT) at the concentrations of $0.5 \%$ and $0.25 \%$, respectively. Data collection and analysis were as described for Trichomix-HV. Nontreated infested soil and those immersed in water were also used for growing the cucumber seedlings to serve as control. The design used for this experiment was a complete randomized design (CRD) with four replications. Experiments were analyzed by analysis of variance (SAS Institute, Cary, NC), and mean separations were according to Duncan multiple range test, $\mathrm{Pd}$ ” 0.001 . 


\section{RESULTS AND DISCUSSION}

Pythium and Phytophthora species were isolated from samples taken from diseased cucumber plants. Of the 504 isolates collected during the survey, $P$. aphanidermatum, P. ultimum, P. irregulare, Phytophthora drechsleri, and Ph. melonis accounted for $9.9 \%, 8.3 \%, 4.5 \%, 4.9 \%$, and $21 \%$ of total isolates respectively. These species were identified by comparison of cultural and morphological characteristics to literature and reference isolates (Plaats-Niterink, 1981). Among 504 isolates from decayed roots and crowns, 50 (9.9\%) were identified as $P$. aphanidermatum. This pathogen was detected in $30 \%$ of the visited greenhouses of Jiroft.

Activity of synthetic fungicides and the biofungicide versus $P$. aphanidermatum

Fungicides used during the present study produced a gradual decline in growth of $P$. aphanidermatum by increasing concentration in the medium (Table 1). Metalaxyl was found to be the most effective, providing $85 \%$ reduction in growth of $P$. aphanidermatum at a concentration of $0.5 \mathrm{ppm}$ (Table 2). Metalaxyl MZ was the second most effective product with a $78 \%$ reduction in the $0.5 \mathrm{ppm}$ treatment, however, its efficacy was not significantly different from that of Metalaxyl.

For testing the inhibitory effect of Trichomix-HV biocontrol commercial product on mycelia growth of $P$. aphanidermatum isolates, $T$. harzianum strain T969 was used as the main effective ingredient of Trichomix-HV biological product directly on media because of its high contaminating effect on medium cultures. Results showed that the inhibition of radial mycelia growth of tested Pythium isolates was not greater than that provided by the compared fungicides when T. harzianum strain T969 was used versus the pathogen on medium 5 days after treatment (Table 3).

In studying $T$. harzianum strain T969 and the pathogen species in simultaneous and nonsimultaneous dual cultures, Trichoderma had a marked inhibitory effect on the pathogen growth compared with the control, however, with different efficiency in the in vitro test. Trichoderma was most effective in pathogen mycelial growth inhibition when it was cultured before inoculating Pythium on the medium (Table 3). Compared to fungicides, T. harzianum showed a lower inhibitory effect on Pythium mycelial growth on PDA.

Table 1: Reduction in growth of Pythium aphanidermatum on potato dextrose agar containing different concentration of the fungicides

\begin{tabular}{|c|c|c|c|c|c|c|c|c|c|}
\hline & \multicolumn{6}{|c|}{ Doses (ppm) } & & & \\
\hline Fungicide (common name) & Control* & 0.01 & 0.1 & 0.5 & 1 & 5 & 10 & 50 & 100 \\
\hline Metalaxyl $\quad(5 \%$, WG $)$ & $5.6^{\mathrm{a}}$ & 3.3 & 1.7 & 0.8 & 0 & 0 & 0 & 0 & 0 \\
\hline Metalaxyl MZ ( 72\%, WT) & 5.6 & 3.6 & 2.3 & 1.2 & 0 & 0 & 0 & 0 & 0 \\
\hline
\end{tabular}

Table 2: Percentage inhibition of radial mycelia growth of $P$. aphanidermatum

\begin{tabular}{|c|c|c|c|c|c|c|c|c|c|}
\hline \multicolumn{10}{|c|}{ Doses (ppm) } \\
\hline Fungicide (common name) & Control* & 0.01 & 0.1 & 0.5 & 1 & 5 & 10 & 50 & 100 \\
\hline Metalaxyl $(5 \%, W G)$ & 0 & 41 & 69 & 85 & 100 & 100 & 100 & 100 & 100 \\
\hline Metalaxyl MZ (72\%,WT) & 0 & 35 & 58 & 78 & 100 & 100 & 100 & 100 & 100 \\
\hline
\end{tabular}

Each value is an average of 10 replicates combined from four experiments (10 seeds planted per replicate).* Water used as control

Table 3: Percentage inhibition of radial mycelial growth of $P$. aphanidermatum in simultaneous and non-simultaneous dual culture assays

\begin{tabular}{|c|c|c|c|c|c|c|c|c|}
\hline & \multicolumn{4}{|c|}{ simultaneous dual culture } & \multicolumn{4}{|c|}{ non-simultaneous dual culture } \\
\hline DAI & 2 & 3 & 4 & 5 & 2 & 3 & 4 & 5 \\
\hline Trichoderma harzianum strain T969 & $28.44^{\mathrm{a}}$ & 34.11 & 39.33 & 55.12 & 64.69 & 67.37 & 69.35 & 74.48 \\
\hline
\end{tabular}

DAI = Days after inoculation. ${ }^{a}$ Numbers within a column are mean value of 8 replicates per treatment 
Evaluation of the biofungicide Trichomix-HV and chemical fungicides under greenhouse conditions

Control of damping-off provided by the fungicides Metalaxyl and Metalaxyl MZ was high in non-sterilized greenhouse soils, with inhibition rates of $77 \%$ and 17 $\%$, respectively compared to Trichomix-HV with an inhibition rate of $68.6 \%$ (Fig. 2). A significant increase of damping-off control was obtained when TrichomixHV was applied in pre-sterilized greenhouse soil, resulting in efficient control of damping-off up to 82 \%, compared to Metalaxyl (73.7 \%) and Metalaxyl MZ (17 \%) (Fig. 1). When water, as a control,was added into pre-sterilized and non-sterilized greenhouse soils, no damping-off inhibition was observed.
The results of this study showed that most of the visited greenhouses in Jiroft are infected with at least one species of the fungal-like oomycete causing damping-off on cucumber plants. It was also observed that $P$. aphanidermatum was the most prevalent Pythium species in the region of interest. It is important for growers to know which Pythium species occurs in their cropping soils and the overall levels of inoculum that they have to deal with to decide when to use biocontrol agents or fungicides for maximum impact. Soilborne plant pathogens such as bacteria, fungi and nematodes annually create major economic losses in many important crops. Some chemical compounds have been successfully used to control soilborne plant

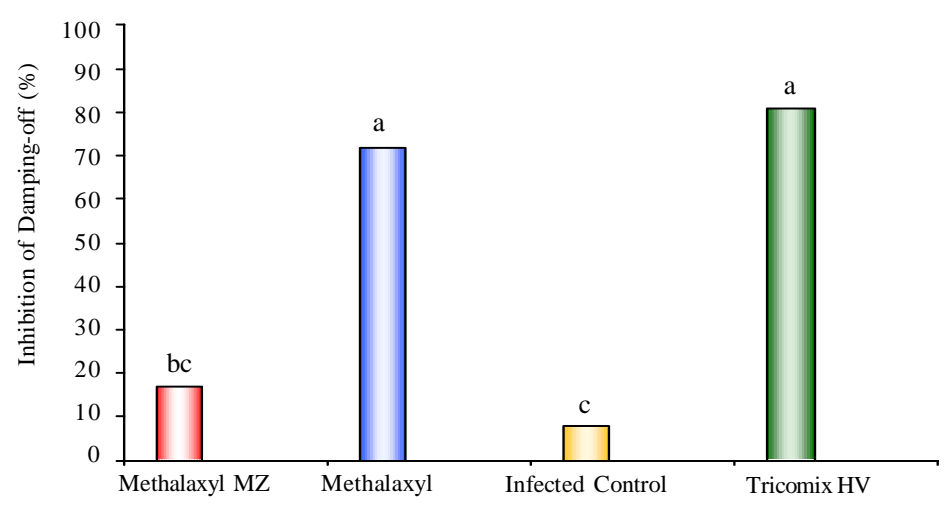

Fig. 1: Efficacy of the commercial biofungicide Trichomix-HV, in comparison with two chemical fungicides. Bars followed by common letters do not differ significantly according to Duncan multiple range test (Pd” 0.001)

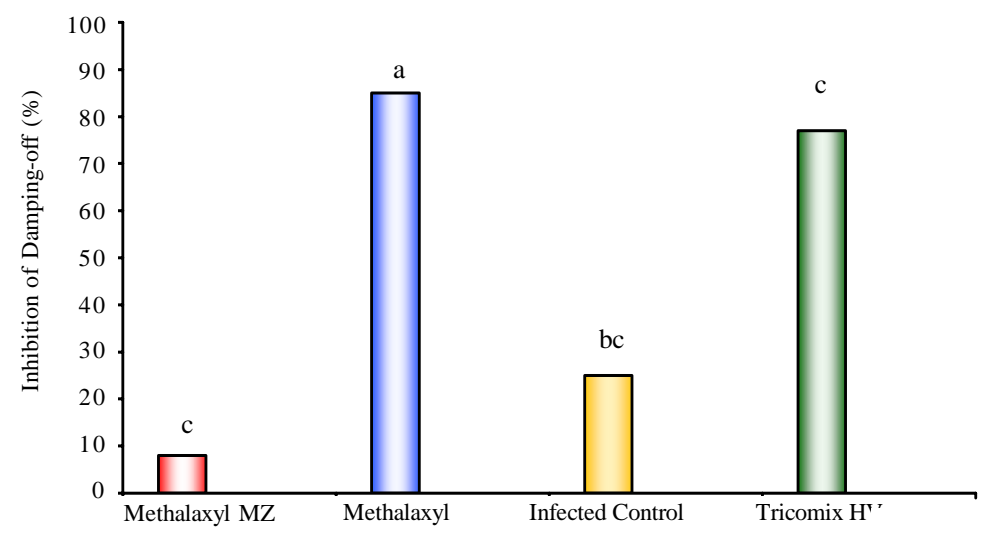

Fig. 2: Efficacy of the commercial biofungicide Trichomix-HV, in comparison with two chemical fungicides. Bars followed by common letters do not differ significantly according to Duncan multiple range test (Pd” 0.001) 
pathogens. In this study, the inhibitory effect of Metalaxyl and Metalaxyl MZ fungicides on $P$. aphanidermatum was evaluated. The results indicate a high inhibitory effect of these fungicides on Pythium under in vitro and greenhouse conditions. Combined treatments with Trichoderma spp. and fungicides to control plant diseases has been attempted with other crops, using either natural strains or strains selected for fungicide resistance (Howel, 2007). Previous studies have demonstrated the lack of inhibitory effect of Metalaxyl and Metalaxyl MZ on Trichoderma (Singh et al., 1995). This result indicates that mixed applications of Metalaxyl or Metalaxyl MZ with Trichoderma spp. can be possible and then this strategy could be also adopted in Jiroft to lead higher inhibitory effects versus Pythium and lower application rates of the fungicides. In many cases, fungicides appear to be the most economical and efficient means of controlling plant pathogens, however, these products require a variety of other considerations such as evaluation of their environmental impact and toxicological risks. Global policy barring use of active chemicals in the process of agricultural production represents a burden for agricultural farmers dependent on chemical fungicides.

Biological control is a promising strategy for managing soilborne or foliar plant diseases in a wide range of crops (Stack, et al., 1988; Lo et al., 1996). In this research, the efficacy of a new biocontrol product; Trichomix-HV containing in its formulate $T$. harzianum was evaluated as the main active biologic ingredient exerting a strong inhibitory effect against $P$. aphanidermatum on cucumber plants under greenhouse conditions. Results showed that Trichomix-HV is an efficient biocontrol product controlling $P$. aphanidermatum when applied in medium cultures (Tables 1 and 2). However more growth inhibitory effects were obtained when Trichomix-HV was applied in non-simultaneous dual culture under in vitro conditions (Table 2). This suggests that for optimal results Trichomix-HV should be preventively applied before seedling plantation. It agrees with other studies indicating that effective antagonists must become established in cucumber ecosystems and remains active versus target pathogens during periods favorable for plant infection (Nelson et al., 1994).

\section{CONCLUSION}

The antagonistic activity (hyperparasitism, mainly) of the genus Trichoderma versus Pythiym species has been widely demonstrated (Chao, et al., 1986; Yedidia, et al.; 2001). Applications of granules of this fungus resulted in establishment of stable and effective populations in several plant species (Lo, et al., 1996). To be effective, biological disease control depends not only on suitable biocontrol organisms but also on methods and strategies for introducing and maintaining high population level and activity of these organisms in association with crop and plant (Stack, et al., 1988; Jin, et al., 1991). Regardless of the quality of the biocontrol agent, the methods used to produce, formulate, and deliver the active organism may profoundly influence its efficacy (Cook and Baker, 1983; Jin, et al., 1991). For this reason, Pythium inhibitory activity of the commercial biocontrol product Trichomix-HV has been evaluated, in which all of mentioned parameters were considered to be most effective against a pathogen in field. The results confirmed a good antagonistic effect of this product in greenhouse soils (Figs. 1 and 2). No significant difference was found between percentage of damping-off inhibition due to metalaxyl application and Trichomix-HV application in sterilized or nonsterilized soils, supporting the premise that Trichomix-HV is a good substitute for Metalaxyl versus Pythium on cucumber crops under greenhouse conditions. Previously a commercial formulation of $T$. harzianum T39 named Trichodex was tested for its ability to protect potato and tomato plants from disease caused by $P$. erythroseptica in greenhouses in Iran, which was highly effective on tomato plants (Etebarian, et al., 2000). Here, the efficacy of a new commercial formulation of T. harzianum, Trichomix-HV, versus P. aphanidermatum under greenhouse condition on cucumber plants has been demonstrated. The results of this study encourage further investigations in order to better understand Trichomix-HV stability and duration in the soil and its interaction with environmental conditions on cucumber plants.

\section{ACKNOWLEDGMENTS}

Authors would like to thank Fanavaran Hayate Sabz Inc. for its kindly donation of Tricomix-HV also Mr. Omidi for his technical assistance. 


\section{REFERENCES}

Abbasi, P. A.; Conn, K. L.; Lazarovits, G., (2004). Suppression of rhizoctonia and pythium damping-off of radish and cucumber seedlings by addition of fish emulsion to peat mix or soil. Can. J. Plant Pathol., 26 (2), 177-87 (11 pages).

Altomare, C.; Norvell, W. A.; Björkman, T.; Harman, G. E., (1999). Solubilization of phosphates and micronutrients by the plant-growth promoting and biocontrol fungus Trichoderma harzianum Rifai 1295-22. Appl. Env. Microbiol., 65, 2926-2933 (8 Pages).

Bandyopadhyay, G.; Chattopadhyay, S., (2007). Single hidden layer artificial neural network models versus multiple linear regression model in forecasting the time series of total ozone. Int. J. Environ. Sci. Tech., 4 (1), 141-150 (10 pages).

Brantner, J. R.; Windels, C. E., (1998). Variability in Sensitivity to Metalaxyl in vitro, Pathogenicity, and Control of Pythium spp. on Sugar Beet. Plant Dis. 82 (8), 896-899 (4 pages).

Chao, W. L.; Nelson, E. B.; Harman, G. E.; Hoch, H. C., (1986). Colonization of the rhizosphere by biological control agents applied to seeds. Phytopathology., 76 (1), 60-65 (6 pages).

Cook, R. J.; Baker, K. F., (1983). The nature and practice of biological control of plant pathogens. American Phytopathological Society, St. Paul, MN.

Cook, R. J., (1993). Making greater use of introduced microorganisms for biological control of plant pathogens. Annu. Rev. Phytopathol., 31, 53-80 (28 pages).

Cuthbertson, A. G. S.; Blackburn, L. F.; Northing, P.; Mathers, J. J.; Luo, W.; Walters, K. F. A., (2009a). Environmental evaluation of hot water treatments to control Liriomyza huidobrensis infesting plant material in transit. Int. J. Environ. Sci. Tech., 6 (2), 167-174 (8 pages).

Cuthbertson, A. G. S.; Blackburn, L. F.; Northing, P.; Luo, W.; Cannon, R. J. C.; Walters, K. F. A., (2009b). Leaf dipping as an environmental screening measure to test chemical efficacy against Bemisia tabaci on poinsettia plants. Int. J. Environ. Sci. Tech., 6 (3), 347-352 (6 pages).

Cuthbertson, A. G. S.; Brown, M. A., (2009). Issues affecting British honey bee biodiversity and the need for conservation of this important ecological component. Int. J. Environ. Sci. Tech., 6 (4), 695-699 (5 pages).

Cuthbertson, A. G. S.; Blackburn, L. F.; Northing, P.; Luo, W.; Cannon, R. J. C.; Walters, K. F. A., (2010). Chemical compatibility testing of the entomopathogenic fungus Lecanicillium muscarium to control Bemisia tabaci in glasshouse environment. Int. J. Environ. Sci. Tech., 7 (2), 405-409 (5 pages).

Cuthbertson, A. G. S.; Murchie, A. k., (2010). Ecological benefits of Anystis baccarum in an orchard ecosystem and the need for its conservation. Int. J. Environ. Sci. Tech., 7 (4), $807-$ 813 (7 pages).

Davet, P., Rouxel, F., (2000). Detection and isolation of soil fungi. Science Publishers Inc, Enfield, USA.

Deadman, M. L.; Al-Saadi, A.M.; Al-Mahmuli, I.; Al-Maqbali, Y.M.; Al-Subhi, R.; Al-Kiyoomi, K.; Al-Hasani, H.; Thacker, J. R. M., (2002). Management of pythium aphanidermatum in greenhouse cucumber production in the Sultanate of Oman. In: BCPC Conference: Pests and Diseases, 2002, Brighton, UK, 171-176 (6 pages).
Dennis, C.; Webster, J., (1971). Antagonistic properties of species- groups of Trichoderma: III hyphal interaction. Trans. Br. Mycol. Soc., 57 (3), 363-369 (7 pages).

Edington, L. V.; Khew, K. L.; Barron, G.I., (1971). Fungitoxic spectrum of benzimidazole compounds. Phytopathology., 61 (1), 42-44 (3 pages).

Elad, Y.; Kapat, A., (1999). The role of Trichoderma harzianum protease in the biocontrol of Botrytis cinerea. Eur. J. Plant Pathol. 105, 177-189 (13 Pages).

Etebarian, H. R.; Scott, E. S.; Wicks, T. J., (2000). Trichoderma harzianum T39 and T. virens DAR 74290 as potential biological control agents for Phytophthora erythroseptica. Eur. J. Plant Pathol. 106 (4), 329-337 (8 pages).

Farr, D. F.; Bills, G. F.; Chamuris, G. P.; Rossman, A. Y., (1989). Fungi on plants and plant products in the United States. American Phytopathological Society Press, St. Paul, MN.

Goodwin, S. B.; McGrath, M. T., (1995). Insensitivity to metalaxyl among isolates of Phytophthora erythroseptica causing pink rot of potato in New York. Plant Dis., 79, 967-968 (2 pages).

Gubler, W. D.; Davis, R. M., (1996). Pythium and phytophthora damping off and root rot. in: Zitter, T. A., Hopkins, D. L., Thomas, T. C., (Eds.). Compendium of cucurbit diseases. St. Paul, MN, USA., APS Press.

Howell, C. R., (2007). Effect of seed quality and combination fungicide-Trichoderma spp. seed treatments on pre- and postemergence damping off in cotton. Phytopathology., 97 (1), 66-71 (6 pages).

Igbinosa, E. O.; Okoh, A. I., (2009). Impact of discharge wastewater effluents on the physico-chemical qualities of a receiving watershed in a typical rural community. Int. J. Environ. Sci. Tech., 6 (2), 175-182 (8 pages).

Igwe, J. C.; Abia, A. A.; Ibeh, C.A., (2008). Adsorption kinetics and intraparticulate diffusivities of $\mathrm{Hg}$, $\mathrm{As}$ and $\mathrm{Pb}$ ions on unmodified and thiolated coconut fiber. Int. J. Environ. Sci. Tech., 5 (1), 83-92 (10 pages).

Jin, X.; Hayes, C. K.; Harman, G. E., (1991). Principles in the development of biological control systems employing Trichoderma species against soil borne plant pathogenic fungi. Pages 174-195 in: Frontiers in Industrial Mycology. G. C. Leatham, ed. Chapman and Hall, London.

Lida, W.; Hirano, K.; Amemiya, Y.; Mita, Y., (1983). Influence of soil moisture on the incidence of dampingoff of cucumber caused by Fusarium oxysporum f.sp. cucumerinum and Pythium aphanidermatum. Tech. Bull. Facul. Hortic. Chiba Uni., 31, 81-86 (7 pages).

Lo, C. T.; Nelson, E. B.; Harman, G. E., (1996). Biological control of turfgrass diseases with a rhizosphere competent strain of Trichoderma harzianum. Plant Dis., 80 (7), 736-741 (6 pages).

Malakootian, M.; Nouri, J.; Hossaini, H., (2009). Removal of heavy metals from paint industry's wastewater using Leca as an available adsorbent. Int. J. Environ. Sci. Tech., 6 (2), 183-190 (8 pages).

Martin, F. N.; Loper, J. E., (1999). Soilborne plant diseases caused by Pythium spp: Ecology, epidemiology, and prospects for biological control. Crit. Rev. Plant. Sci., 18 (2), 111-181 (71 pages). 
Mubli, M.; Pirasteh, B., (1995). Vegetable production. Eds., Industrial University of Isfahan, Iran.

Nelson, E. B.; Burpee, L. L.; Lawton, M. B., (1994). Biological control of turfgrass diseases. in: Leslie, A. (Ed.), Handbook of integrated pest management for turf and ornamentals. CRC Press, Boca Raton, FL. 409-427

Obire, O.; Anyanwu, E. C., (2009). Impact of various concentration of crude oil un fungal population of soil. Int. J. Environ. Sci. Tech., 6 (2), 211-218 (9 pages).

Plaats-Niterink, A. J., (1981). Monograph of the genus Pythium. studies in mycology, No. 21. Centraalbureau Voor Schimmelcultures, Baarn, Netherlands.

Shafizadeh, S., (2003). Phytophthora root rot- stem canker of noble fir christmas trees in Ireland. Ph.D. Thesis.

Siddiqui, I. A.; Qureshi, S. A.; Sultana, V.; Ehteshamul-Haque, S.; Ghaffer, A., (2000). Biological control of root rot-root knot disease complex of tomato. Plant Soil., 227, 163-169 (7 pages).

Singh, R. S.; Jindal, A.; Singh, D.; Singh, T., (1995). Selection of Trichoderma isolates against common fungicides for their use in integrated plant disease management. Indian J. Mycol. Plant Pathol., 25 (1), 127- 128 (2 pages).

Stack, J. P.; Kenerley, C. M.; Pettit, R. E., (1988). Application of biological control agents, in: K. G. Mukerji; K. L. Garg, (Eds.). Biocontrol of plant disease. CRC Press, Boca Raton, FL. 43-54

Stanghellini, M. E.; Phillips, J. M., (1975). Pythium aphanidermatum: its occurrence and control with pyroxychlor in the Arabian desert at Abu Dhabi. Plant. Dis. Rep., 59, 559-63 (4 pages).
Sultana,V.; Ehteshamul-Haque, S.; Ara, J.; Athar, M., (2005). Comparative efficacy of brown, green and redseaweeds in the control of root infecting fungi and okra. Int. J. Environ. Sci. Tech., 2 (2), 129-132 (4 pages).

Sutton, J. C.; Peng, G., (1993). Manipulation and vectoring of biocontrol organisms to manage foliage and fruit diseases in cropping systems. Annu. Rev. Phytopathol., 31, 473493 (20 pages).

Tsao, P. H., (1983). Factors affecting isolation and quantitation of Phytophthora from soil. in: Erwin, D. C.; Bartnicki, S. Garcia, and Tsao, P. H. (Eds.) Phytophthora its biology, taxonomy, ecology, and pathology. The American Phytopathological Society, St. Paul, Minnesota. 219-263.

Vinodhini, R.; Narayanan, M., (2008). Bioaccumulation of heavy metals in organs of fresh water fish Cyprinus carpio (Common carp). Int. J. Environ. Sci. Tech., 5 (2), 179-182 (4 pages).

Weller, D. M.; Raaijmarkers, J. M.; Gardener, B. B. M.; Thomashow, L. S., (2002). Microbial population responsible for specific soil suppressiveness to plant pathogens. Annu. Rev. Phytopathol., 40, 309-348 (40 pages).

Yedidia, I.; Benhamou, N.; Chet, I., (1999). Induction of defense responses in cucumber plants (Cucumis sativus L.) by the biocontrol agent Trichoderma harzianum. Appl. Environ. Microbiol. 65, 1061-1070 (10 pages).

Yedidia, I.; Srivastva A. K.; Kapulnik, Y.; Chet, I., (2001). Effect of Trichoderma harzianum on microelement concentrations and increased growth of cucumber plants. Plant soil 235, 235-242 (8 pages).

\section{AUTHOR (S) BIOSKETCHES}

Zamanizadeh, H. R., Ph.D., Associated professor, Department of Plant Pathology, Science and Research Branch, Islamic Azad University, Tehran, Iran, Email: hzamani@srb.iau.ac.ir

Hatami, N., Member of Department of Plant Pathology, College of Agriculture, Payam-e nour University, Kerman, Iran. Email: n.hatamy@yahoo.com

Aminaee, M. M., Member of Plant Pest and Disease Research, Kerman Agriculture research Center, Kerman, Iran. Email: mm.aminaee@yahoo.com

Rakhshandehroo, F., Assistant professor, Department of Plant Pathology, Science and Research Branch, Islamic Azad University, Tehran, Iran, Email: rakhshandehroo_fa@srb.iau.ac.ir

How to cite this article: (Harvard style)

Zamanizadeh, H. R.; Hatami, N.; Aminaee, M. M.;F. Rakhshandehroo, (2011). Application of biofungicides in control of damping disease off in greenhouse crops as a possible substitute to synthetic fungicides. Int. J. Environ. Sci. Tech., 8 (1), 129-136. 